\title{
Ulceronodular syphilis (lues maligna praecox) in a person newly diagnosed with HIV infection
}

\author{
John D Kelly, ${ }^{1}$ Todd M LeLeux, ${ }^{2}$ Deborah R Citron, ${ }^{3}$ Daniel M Musher, ${ }^{1}$ Thomas P Giordano ${ }^{1}$
}

${ }^{1}$ Department of Medicine, Baylor College of Medicine, Houston, Texas, USA;

Envision Pathology, LLC, Crowley, Louisiana, USA:

${ }^{3}$ Department of Pathology, Baylor College of Medicine, Houston, Texas, USA

Correspondence to Dr John D Kelly, jdkelly@bcm.edu

\section{Summary}

In this case of secondary syphilis, pustular lesions progressed rapidly to painful ulcerative lesions in a patient with early HIV infection. This rapidly progressive form of early syphilis has historically been called lues maligna praecox, a severe form of noduloulcerative secondary syphilis. Serologic tests for syphilis were positive and biopsy showed forms consistent with Treponema pallidum in the lesions. This case demonstrates how HIV infection may affect presentation and diagnosis of secondary syphilis.

\section{BACKGROUND}

Ulcerative lesions are a rare presentation of syphilis. We initially presented this case at our weekly Infectious Disease Citywide Conference in Houston, and we were met with open scepticism about the lesions being the result of an HIV and syphilis co-infection. Subsequent biopsy results revealed numerous forms consistent with Treponema pallidum in the lesions, and a photographic literature review on syphiloderma

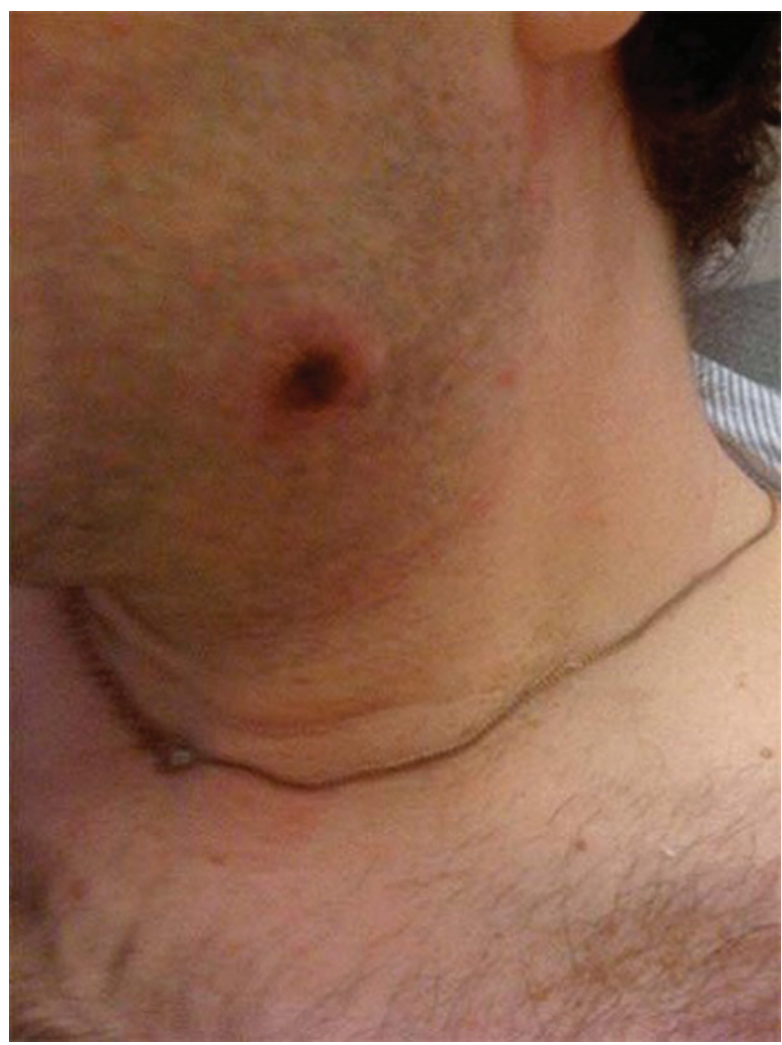

Figure 1 The face (left mandible) is a typical location for ulcerative syphilides. ulcerativum from the 1800s (pre-HIV era) supported our case report. We wrote about this unusual presentation of a common disease to remember a forgotten form of syphilis.

\section{CASE PRESENTATION}

A 34-year-old man with newly diagnosed HIV infection presented with 1 month of progressive, painful nodular and ulcerative skin lesions.

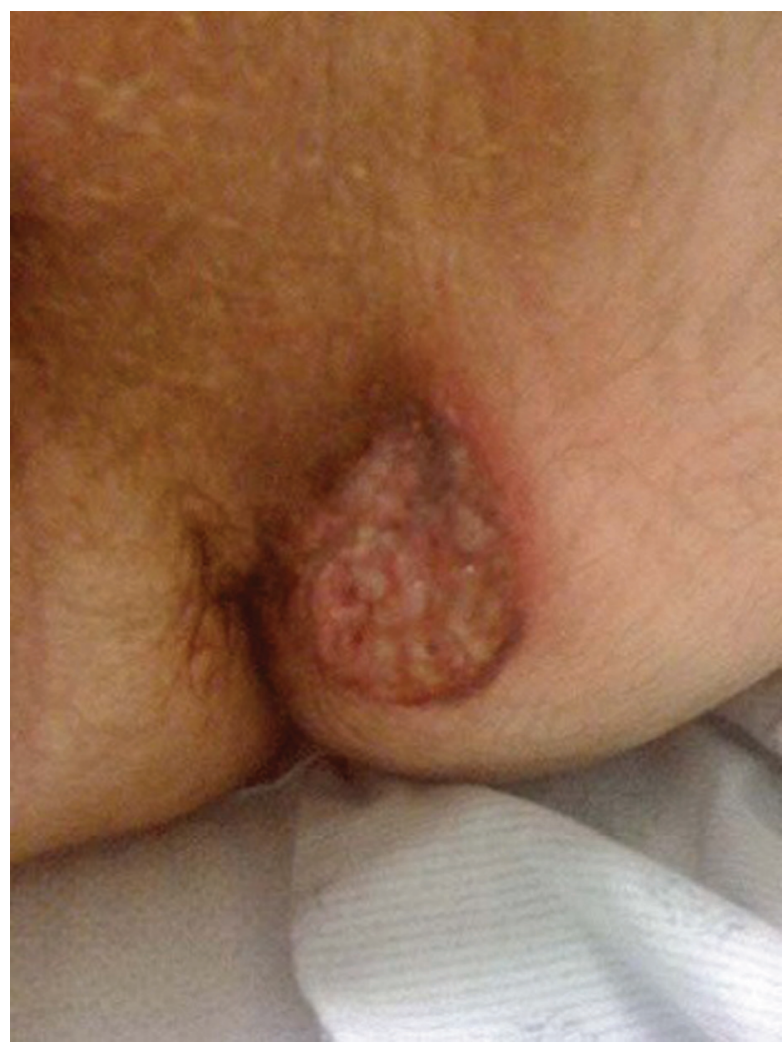

Figure 2 The ulcerative syphilide at the gluteal fold appears in the distribution of condyloma lata (kissing lesions). 


\section{BMJ Case Reports}

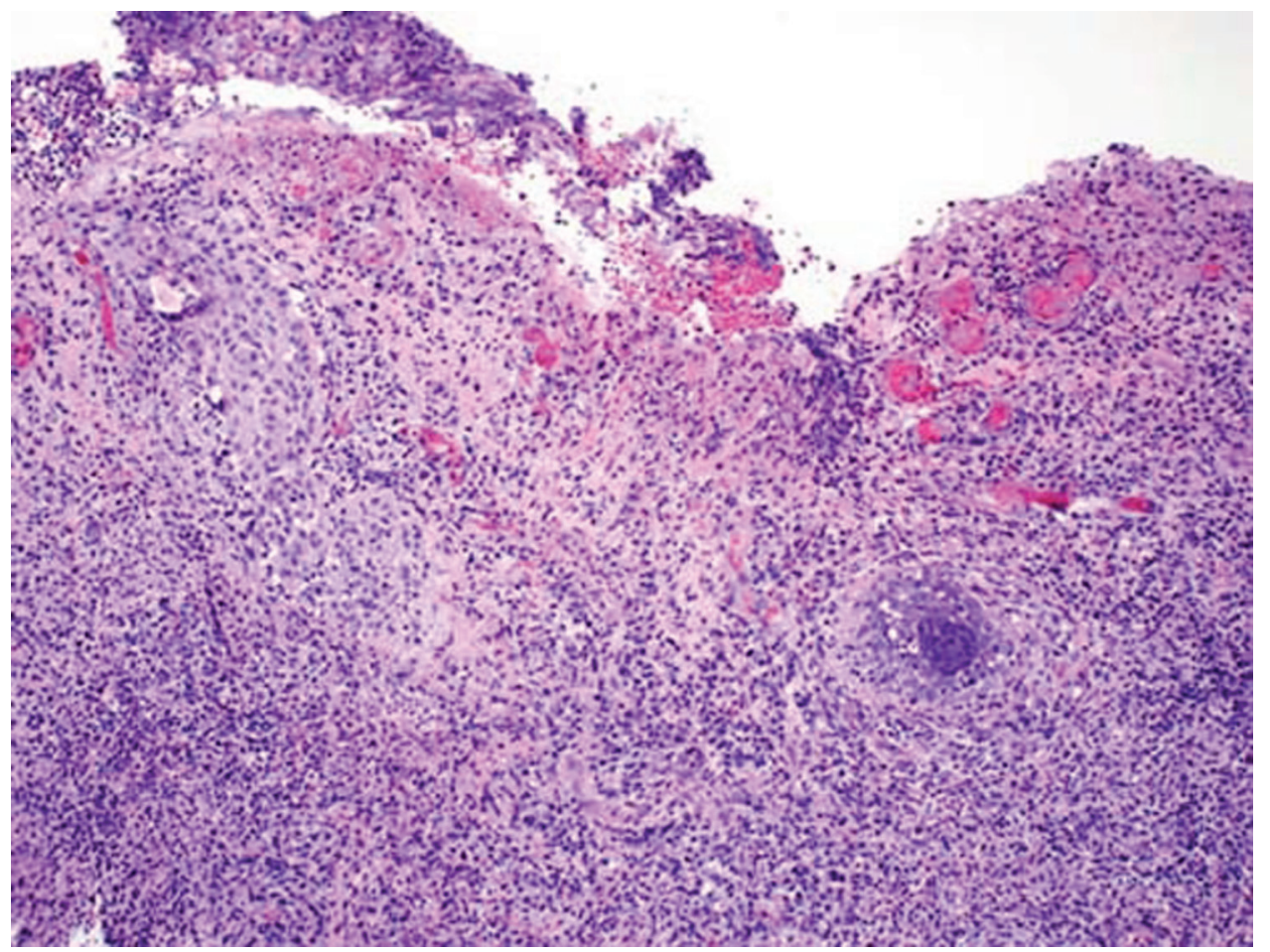

Figure 3 Low power view shows subtotal epidermal ulceration and a dense mixed inflammatory infiltrate within the superficial and deep dermis.

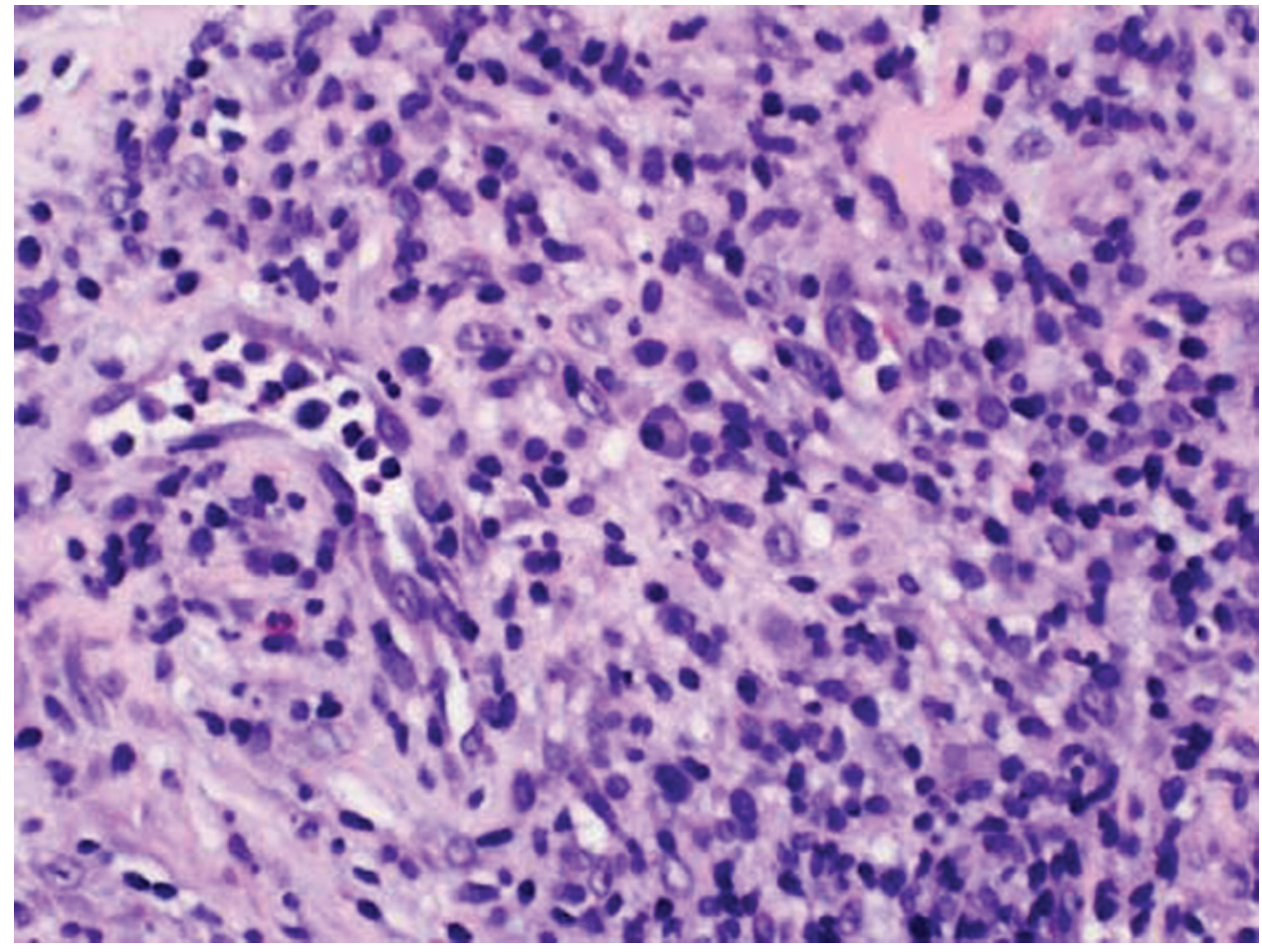

Figure 4 High power view illustrates reactive endothelial cells and scattered plasma cells, eosinophils and neutrophils within a dense lymphohistiocytic inflammatory infiltrate.

Four months before presentation, he had a diffuse, maculopapular rash that spared his palms and soles together with subjective fevers, rhinorrhoea and a sore throat. His primary care physician gave him medications for presumptive chickenpox and, within 1 month, the rash resolved.

One month before admission, he developed pustules, some of which enlarged and ulcerated. They were large 


\section{BMJ Case Reports}

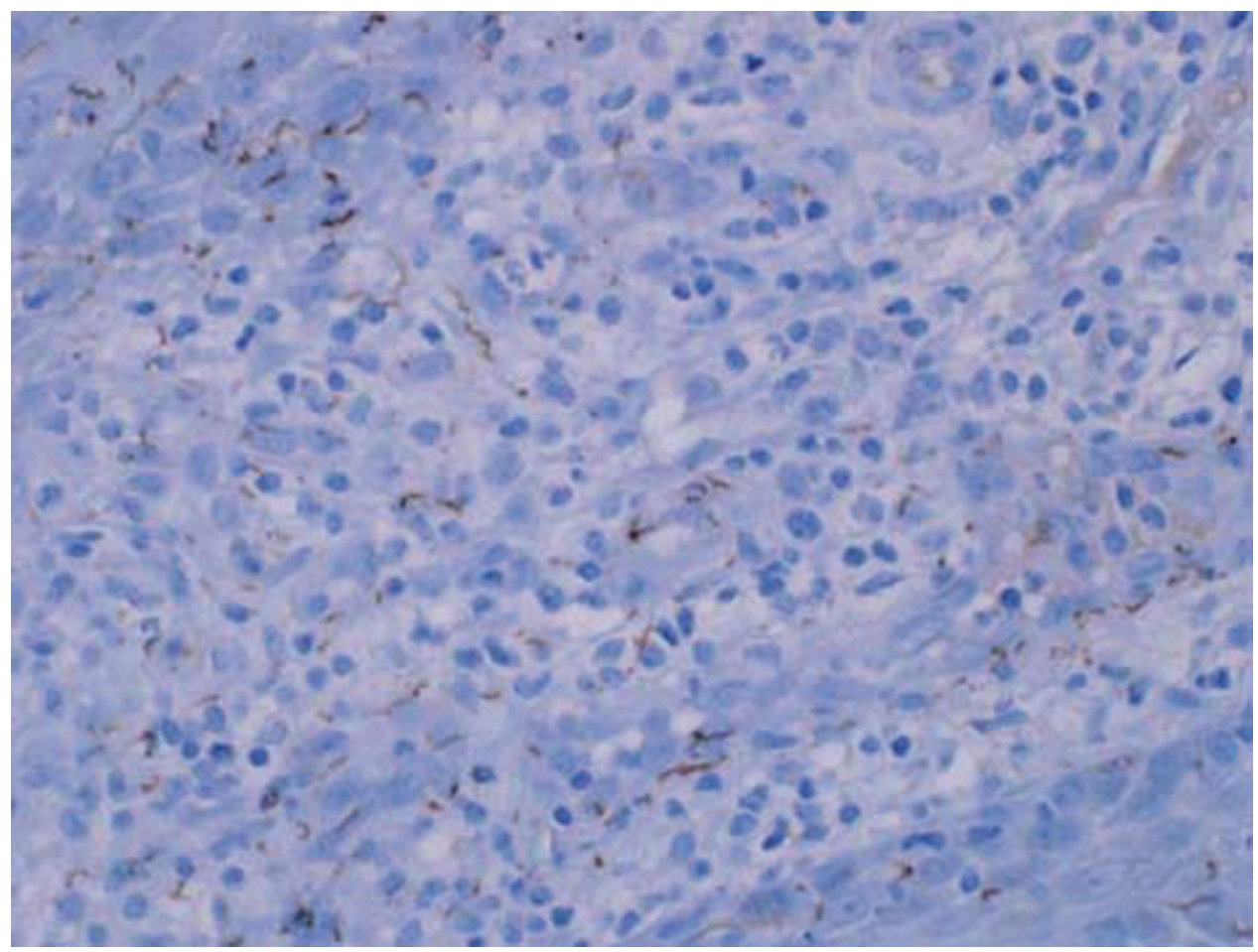

Figure 5 Immunohistochemical stain directed against spirochetes reveals numerous corkscrew-shaped microorganisms, consistent with the morphology of $T$ pallidum.

and varied in depth and circumference along his left mandible, right axilla, right chest wall and left perineal region. His primary care physician prescribed clindamycin.

Two weeks before admission, the patient presented to the emergency room because his ulcers were worse and now had become painful. He reported no fevers, chills, night sweats, weight loss, recent illness or sick contacts. When the pain became unbearable, he re-presented to emergency room and was admitted for further evaluation. He reported a negative HIV test and negative rapid plasma reagin (RPR) approximately 12 months before admission.

The patient had normal vital signs. He was in mild distress. The skin had scattered pustules and approximately 10 ulcerative lesions ranging from $1 \times 1 \mathrm{~cm}$ to $3 \times 5 \mathrm{~cm}$ were present on his trunk, face, arms, axilla and gluteal fold. The largest one extended to muscle while the smallest one did not extend beyond subcutaneous tissue. The borders were well demarcated and erythematous with associated crusting (figures 1 and 2). He had no genital lesions, but a rectal fissure was present. Neurologic examination revealed intact cranial nerves, normal sensation and a normal gait.

\section{INVESTIGATIONS}

His complete blood count was normal as were other routine laboratory tests. RPR was positive at 1:64 and Treponema pallidum particle agglutination assay was positive. HIV enzyme immunoassay and Western blot were positive. HIV-1 viral load was 930 000, and CD4 count was 408 cells $/ \mathrm{mm}^{3}$ with $17 \%$ CD4 cells.

Wound cultures showed normal skin flora. Skin punch biopsy showed necroinflammatory debris lining the ulcer base, with a dense mixed inflammatory infiltrate of lymphocytes, histiocytes, plasma cells, neutrophils and eosinophils permeating the superficial and deep dermis. The vascular plexus contained reactive and swollen endothelial cells with mild proliferation (figures 3 and 4). Fite's acid fast, Gomori methenamine silver and gram stains were negative. Herpes simplex virus was not detected. An immunohistochemical stain directed against spirochetes demonstrated numerous corkscrew-shaped microorganisms (figure 5).

\section{TREATMENT}

The patient was treated with three doses of $2.4 \times 10^{6}$ units of benzathine penicillin at weekly intervals. Close clinical monitoring confirmed that he did not have a JarischHerxheimer (JHR) reaction.

\section{OUTCOME AND FOLLOW-UP}

One month after the first dose of penicillin, his ulcers had formed scars that completely healed, and his pain had fully resolved.

\section{DISCUSSION}

This patient with HIV infection of recent onset was diagnosed as having lues maligna praecox - a rare but severe form of secondary syphilis. Numerous pustular lesions appeared. Over a period of several weeks, the lesions progressed to extremely painful ulcerations. In the preantibiotic era, such lesions were called ulcerative syphilides. ${ }^{12}$

Although lues maligna was described well before the HIV pandemic, ${ }^{3}$ more cases of lues maligna have been described in people with HIV infection. ${ }^{4-7}$ Persons living with HIV/AIDS are 60 times more likely to present with this form of syphilis. ${ }^{8}$ Immunologic events that facilitate the development of lues maligna are unknown, but it is 


\section{BMJ Case Reports}

reasonable to postulate that the loss of helper $\mathrm{T}$ cells is responsible. CD4 cell counts have been low in those few previous cases in which they have been reported. These findings suggest that people with acute HIV infection may be an at-risk population.

The lesions of lues maligna may present a diagnostic dilemma in the HIV population. Physicians rely on the following diagnostic criteria developed in the pre-HIV syphilis era: (1) compatible gross and microscopic morphology; (2) a high titre serologic test for syphilis; (3) a severe JHR; and (4) dramatic response to antibiotic therapy. 9 Our patient met only two of these four diagnostic criteria for lues maligna: comparable gross appearance and a dramatic response to penicillin. Of course, the immunohistologic stains for treponemes were not available when the original criteria were developed.

We diagnosed secondary syphilis instead of tertiary syphilis based on the biopsy findings. The lesion showed a mixed inflammatory infiltrate with epidermal ulceration rather than the expected plasma cell predominant dermatitis. ${ }^{4}$ Treponemes are rarely detected in syphilitic gummas, although in one case, treponemes were detected using indirect immunofluoresence. ${ }^{10}$ In our case, the presence of numerous treponemes on immunohistochemical stain diagnosed secondary syphilis with certainty and excluded the possibility of a gumma.
Acknowledgements The authors would like to thank the patient for sharing his story.

\section{Competing interests None.}

Patient consent Obtained.

\section{REFERENCES}

1. Fox GH. Cutaneous syphilis. In: Photographic Illustrations of Skin Diseases. New York, NY: E.B. Treat 1881;53,65-68,81-83.

2. States WG, Kingsbury J. Syphilis. In: Portfolio of Dermochromes. Volume 3. New York, NY: Rebman Company 1913;306-8.

3. Lejman K, Starzycki Z. Syphilis maligna praecox. A case report. Br J Vener Dis 1972; 48:194-9.

4. Tucker JD, Shah $S$, Jarell AD, et al. Lues maligna in early HIV infection case report and review of the literature. Sex Transm Dis 2009:36:512-14.

5. Shulkin D, Tripoli L, Abell E. Lues maligna in a patient with human immunodeficiency virus infection. Am J Med 1988;85:425-7.

6. Prasad PV, Paari T, Chokkalingam K, et al. Malignant syphilis (leus maligna) in a HIV infected patient. Indian J Dermatol Venereol Leprol 2001;67:192-4.

7. D'Amico R, Zalusky R. A case of lues maligna in a patient with acquired immunodeficiency syndrome (AIDS). Scand J Infect Dis 2005;37:697-700.

8. Schöfer H, Imhof M, Thoma-Greber E, et al. Active syphilis in HIV infection: a multicentre retrospective survey. The German AIDS Study Group (GASG) Genitourin Med 1996;72:176-81.

9. Fisher DA, Chang LW, Tuffanelli DL. Lues maligna. Presentation of a cas and a review of the literature. Arch Dermatol 1969;99:70-3.

10. Handsfield HH, Lukehart SA, Sell S, et al. Demonstration of Treponema pallidum in a cutaneous gumma by indirect immunofluorescence. Arch Dermatol 1983;119:677-80.

\section{Learning points}

- Lues maligna praecox is a rare but severe form of secondary syphilis in which pustular lesions progress rapidly to painful ulcerative lesions.

- HIV infection may affect presentation and diagnosis of secondary syphilis.

- Persons living with HIV/AIDS are 60 times more likely to present with this form of syphilis.

- The presence of numerous treponemes on immunohistochemical stain can diagnose secondary syphilis with certainty and exclude the possibility of a gumma.

This pdf has been created automatically from the final edited text and images.

Copyright 2011 BMJ Publishing Group. All rights reserved. For permission to reuse any of this content visit http://group.bmi.com/group/rights-licensing/permissions.

BMJ Case Report Fellows may re-use this article for personal use and teaching without any further permission.

Please cite this article as follows (you will need to access the article online to obtain the date of publication).

Kelly JD, LeLeux TM, Citron DR, Musher DM, Giordano TP. Ulceronodular syphilis (lues maligna praecox) in a person newly diagnosed with HIV infection. BMJ Case Reports 2011;10.1136/bcr.12.2010.3670, date of publication

Become a Fellow of BMJ Case Reports today and you can:

- Submit as many cases as you like

- Enjoy fast sympathetic peer review and rapid publication of accepted articles

- Access all the published articles

- Re-use any of the published material for personal use and teaching without further permission

For information on Institutional Fellowships contact consortiasales@bmjgroup.com

Visit casereports.bmj.com for more articles like this and to become a Fellow 